\title{
Genetic Diversity Studies Based on Principal Component Analysis For Yield Attributes in Cassava Genotypes
}

\author{
B. Babu Rao ${ }^{1 *}$, D.V. Swami ${ }^{1}$, P. Ashok ${ }^{1}$, B. Kalyana Babu ${ }^{2}$, \\ D. Ramajayam ${ }^{3}$ and K. Sasikala ${ }^{1}$ \\ ${ }^{1}$ Department of Horticulture, 4 Department of Agronomy, Dr. Y.S.R. Horticultural University, \\ Venkataramannagudem, West Godavari, A.P - 534101, India \\ ${ }^{2}$ ICAR-Indian Institute of Oil Palm Research, Pedavegi, A.P - 534450, India \\ ${ }^{3}$ ICAR-National Research Centre for Banana, Tiruchirapally, T.N - 620102, India
}

*Corresponding author

Key w o r d s
Cassava, Principal
component analysis,
Variability, Genetic
diversity

The present investigation entitled was carried out with seventy seven cassava genotypes along with three check varieties in order to study the variability for different yield attributing characters by Principal components analysis during the period from 2015 to 2016. Principal components analysis showed that, six components with eigen value more than one explained $73.16 \%$ of the cumulative variation among traits. Principal component one (PC1) with eigen value of 3.60 , contributed $22.49 \%$ of the total variability, PC2, with eigen value of 2.13 , revealed $13.31 \%$ of total variability, PC3 had eigen value of 1.95 and contributed with $12.20 \%$ to the total observed variability, PC4, with eigen value of 1.61 , contributed $10.06 \%$ of the total variability, PC5 had eigen value of 1.27 and contributed with $7.93 \%$ to the total observed variability, while PC6, with eigen value of 1.15 , accounted for $7.17 \%$ of total variability observed among the 80 cassava genotypes. The cumulative variance of $73.16 \%$ by the first six components with eigen values of $>1.0$ indicates that the identified traits within these components exhibited great influence on the phenotype of the cassava genotypes and could effectively be used for the selection among them.

\section{A B S T R A C T}

\section{Introduction}

Cassava (Manihot esculenta Crantz) is a perennial shrub, commonly known as tapioca, mandioca, manioc and yuca in different parts of the world. It belongs to the family Euphorbiaceae, sub family Crotonoidea and tribe Manihotae (Alves, 2002; and Jennings and Iglesias, 2002). It is mainly cultivated for its starchy tubers and grown as staple food and animal feed in tropical and sub tropical Africa, Asia and Latin America. It provides more than half of the calories consumed by more than 800 million people in Sub-Saharan Africa (SSA), Latin America and Asia (Shore, 2002). The success of a breeding programme relies mainly on the knowledge of the available germplasm, especially genetic diversity (Meredith and Bridge, 1984). Multivariate methods such as principal component analysis 
(PCA) have proven to be useful for evaluating and classifying germplasm when a large number of accessions are assessed for several characteristics of agronomic importance. Therefore, the present study was planned with the objective to evaluate eighty genotypes of cassava (Manihot esculenta Crantz.) into most discriminating yield attributing traits and to identify the most divergent genotypes in terms of genetic variability for use in efficient breeding programs based on sixteen yield attributing traits by using principle component analysis.

\section{Materials and Methods}

The experiment was conducted with seventy seven cassava genotypes along with three check varieties (Table 1) during 2015 to 2016 at Horticultural Research Station, Venkataramannagudem, Dr.Y.S.R. Horticultural University, Andhra Pradesh, India under All India Co-ordinated Research Project on Tuber crops. The experiment was laid out in Augmented Block Design (ABD) consisting of seven augmented blocks in which three checks and eleven entries were planted. All the genotypes were collected from AICRP on Tuber crops, Venkataramannagude. Observations were recorded on five randomly selected plants for following traits i.e. petiole length, total leaf area, plant dry matter content, tuber dry matter content, number of leaves per plant, plant height, stem diameter, number of storage roots per plant, number of commercial roots per plant, tuber length, tuber diameter, harvest index, starch content, HCN content, postharvest physiological deterioration and tuber yield used for statistical analysis. PCA was performed as per the method suggested by Jackson (1991).

\section{Results and Discussion}

Principal Component Analysis (PCA) for yield and its component characters was performed by adopting correlation matrix method. The principal components, eigen values, per cent variability, cumulative per cent of variability and component loading of different quantitative characters studied are furnished in table 2 and Figure 1. The principal components with eigen values less than one were considered to be non-significant as per the procedure. In the present investigation, six principal components with eigen values more than one contributed to 73.16 per cent of cumulative variability among the 80 genotypes of cassava evaluated for 16 quantitative characters.

The first principal component (PC I) contributed the highest values towards variability $(22.49 \%)$. The character loading values for principal components represented the weights defining the contribution of different characters for the respective principal components (Table 3 and Fig. 2). Characters like petiole length (0.07), total leaf area $(0.34)$, plant dry matter content (0.15), tuber dry matter content (0.18), number of leaves per plant (0.30), plant height (0.32), stem diameter (0.26), number of storage roots per plant (0.29), number of commercial roots per plant (0.32), tuber length $(0.25)$, tuber diameter (0.27), harvest index (0.16), starch content (0.17), HCN content (0.21) and tuber yield (0.36) showed positive loadings explained the maximum variance in the first principal component $\left(\mathrm{PC}_{1}\right)$. This suggests that this component reflects total leaf area, number of leaves per plant, plant height, stem diameter, number of storage roots per plant, number of commercial roots per plant, tuber length, tuber diameter and tuber yield of each genotype. The second principal component $\left(\mathrm{PC}_{2}\right)$, which described $13.31 \%$ of the total variance, reflected significant loadings of stem diameter (0.32), harvest index (0.31), petiole length (0.26), tuber diameter (0.26), plant dry matter content (0.26) and tuber yield (0.25), starch content $(-0.33)$, total leaf area $(-0.30)$ and 
postharvest physiological deterioration $(-0.29)$ were noted to explain maximum variability. This suggests that this component reflects stem diameter, harvest index, petiole length, tuber diameter, plant dry matter content and tuber yield of each genotype. Aina et al., (2007), Raghu et al., (2007) Asare et al., (2011) and Babu Rao et al., (2016) also reported the first two principal components accounting maximum for total variation.

The third principal component $\left(\mathrm{PC}_{3}\right)$ contributed 12.20 per cent of total variance and characterized by number of storage roots per plant (0.31), stem diameter $(0.28)$, number of commercial roots per plant $(0.26)$, tuber dry matter content (-0.44), plant dry matter content $(-0.42)$ and number of leaves per plant $(-0.35)$. This suggests that this component reflects number of storage roots per plant, stem diameter and number of commercial roots per plant. The fourth principal component $\left(\mathrm{PC}_{4}\right)$ contributed 10.06 per cent of total variance and characterized by conspicuously high loadings of tuber dry matter content (0.40), number of storage roots per plant (0.37), number of commercial roots per plant (0.36), plant dry matter content (0.33), tuber diameter $(-0.34)$, harvest index ($0.32)$, tuber length $(-0.29)$ and it suggests that this component reflects tuber dry matter content, number of commercial roots per plant, plant dry matter content. The fifth principal component $\left(\mathrm{PC}_{5}\right)$ contributed 7.93 per cent of total variance and characterized by conspicuously high loadings of petiole length (0.51), total leaf area (0.38), number of leaves per plant (0.31), stem diameter (0.29), number of storage roots per plant $(-0.24)$, tuber length $(-0.24)$, number of commercial roots per plant $(-0.22)$ and it suggest that this component reflects petiole length, total leaf area, number of leaves per plant and stem diameter.

Fig.1 The relative position of cassava genotypes based on PCA scores of quantitative characters

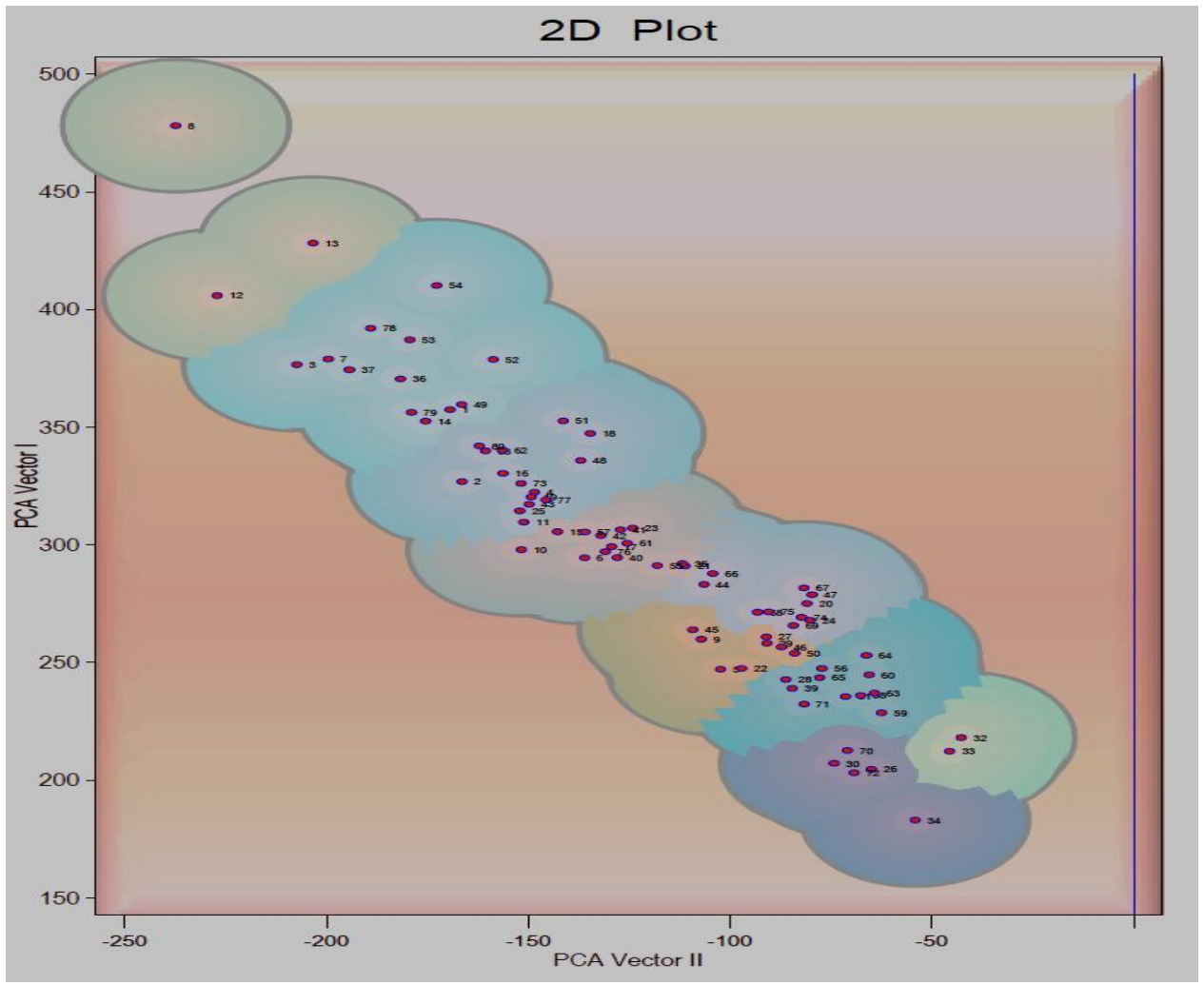


Table.1 Particulars of cassava genotypes under present study

\begin{tabular}{|c|c|c|c|}
\hline S.No & Name of the genotype & S.No & Name of the genotype \\
\hline 1. & Me Ap-1 & 41. & Me Ap-48 \\
\hline 2. & Me Ap-2 & 42. & Мe Ap-49 \\
\hline 3. & Me Ap-3 & 43. & Me Ap-50 \\
\hline 4. & Me Ap-4 & 44. & Me Ap-51 \\
\hline 5. & Me Ap-5 & 45. & Me Ap-52 \\
\hline 6. & Me Ap-6 & 46. & Me Ap-53 \\
\hline 7. & Me Ap-7 & 47. & Me Ap-54 \\
\hline 8. & Me Ap-8 & 48. & Me Ap-55 \\
\hline 9. & Мe Ap-9 & 49. & Мe Ap-56 \\
\hline 10. & Me Ap-10 & 50. & Me Ap-57 \\
\hline 11. & Me Ap-11 & 51. & Мe Ap-58 \\
\hline 12. & Me Ap-12 & 52. & Мe Ap-59 \\
\hline 13. & Me Ap-13 & 53. & Me Ap-60 \\
\hline 14. & Me Ap-14 & 54. & Мe Ap-61 \\
\hline 15. & Me Ap- 15 & 55. & Me Ap-62 \\
\hline 16. & Me Ap-16 & 56. & Me Ap-63 \\
\hline 17. & Me Ap-17 & 57. & Me Ap-64 \\
\hline 18. & Me Ap-18 & 58. & Me Ap-65 \\
\hline 19. & Me Ap-19 & 59. & Мe Ap-66 \\
\hline 20. & Me Ap-20 & 60. & Me Ap-67 \\
\hline 21. & Me Ap-21 & 61. & Мe Ap-68 \\
\hline 22. & Me Ap-22 & 62. & Мe Аp-69 \\
\hline 23. & Me Ap-23 & 63. & Me Ap-70 \\
\hline 24. & Me Ap-24 & 64. & Me Ap-71 \\
\hline 25. & Me Ap- 25 & 65. & Me Ap-72 \\
\hline 26. & Me Ap-26 & 66. & Me Ap-73 \\
\hline 27. & Me Ap-34 & 67. & Me Ap-74 \\
\hline 28. & Me Ap-35 & 68. & Me Ap-75 \\
\hline 29. & Me Ap-36 & 69. & Мe Ap-76 \\
\hline 30. & Me Ap-37 & 70. & Me Ap-77 \\
\hline 31. & Me Ap-38 & 71. & Me Ap-78 \\
\hline 32. & Me Ap-39 & 72. & Me Ap-79 \\
\hline 33. & Me Ap-40 & 73. & Мe Ap-29 \\
\hline 34. & Me Ap-41 & 74. & Me Ap-30 \\
\hline 35. & Me Ap-42 & 75. & Me Ap-31 \\
\hline 36. & Me Ap-43 & 76. & Me Ap-32 \\
\hline 37. & Me Ap-44 & 77. & Me Ap-33 \\
\hline 38. & Me Ap-45 & 78. & H-165 (Check 1) \\
\hline 39. & Me Ap-46 & 79. & H-226 (Check 2) \\
\hline 40. & Me Ap-47 & 80. & Sree Vijaya (Check 3) \\
\hline
\end{tabular}


Table.2 Eigen values, per cent variability and cumulative variability for principal components of quantitative characters in cassava genotypes

\begin{tabular}{|l|l|l|l|l|l|l|l|}
\hline & PC1 & PC2 & PC3 & PC4 & PC5 & PC6 & PC7 \\
\hline Eigen Value & 3.60 & 2.13 & 1.95 & 1.61 & 1.27 & 1.15 & 0.80 \\
\hline $\begin{array}{l}\text { Per cent of variance } \\
\text { explained }\end{array}$ & 22.49 & 13.31 & 12.20 & 10.06 & 7.93 & 7.17 & 4.97 \\
\hline $\begin{array}{l}\text { Cumulative variance } \\
\text { explained }\end{array}$ & 22.49 & 35.80 & 47.99 & 58.05 & 65.99 & 73.16 & 78.14 \\
\hline
\end{tabular}

Table.3 Characters loading of principal components for quantitative characters in cassava genotypes

\begin{tabular}{|c|c|c|c|c|c|c|c|c|}
\hline S.No. & Character & PC1 & PC2 & PC3 & PC4 & PC5 & PC6 & PC7 \\
\hline 1. & Petiole length $(\mathrm{cm})$ & 0.07 & 0.26 & 0.19 & 0.08 & 0.51 & 0.21 & 0.46 \\
\hline 2. & Total leaf area $\left(\mathrm{m}^{2}\right)$ & 0.34 & -0.30 & -0.20 & 0.01 & 0.38 & 0.13 & -0.16 \\
\hline 3. & Plant dry matter content (\%) & 0.15 & 0.26 & -0.42 & 0.33 & -0.21 & -0.15 & 0.15 \\
\hline 4. & Tuber dry matter content (\%) & 0.18 & 0.18 & -0.44 & 0.40 & -0.08 & -0.03 & 0.21 \\
\hline 5. & Number of leaves per plant & 0.30 & -0.26 & -0.35 & -0.07 & 0.31 & 0.24 & -0.21 \\
\hline 6. & Plant height $(\mathrm{cm})$ & 0.32 & -0.06 & 0.20 & -0.17 & 0.13 & -0.23 & 0.21 \\
\hline 7. & Stem diameter $(\mathrm{cm})$ & 0.26 & 0.32 & 0.28 & 0.13 & 0.29 & -0.02 & 0.09 \\
\hline 8. & $\begin{array}{l}\text { Number of storage roots } \\
\text { per plant }\end{array}$ & 0.29 & -0.16 & P0.31 & 0.37 & -0.24 & -0.06 & 0.02 \\
\hline 9. & $\begin{array}{l}\text { Number of commercial roots } \\
\text { per plant }\end{array}$ & 0.32 & -0.19 & 0.26 & 0.36 & -0.22 & 0.16 & -0.09 \\
\hline 10. & Tuber length $(\mathrm{cm})$ & 0.25 & 0.11 & 0.22 & -0.29 & -0.24 & 0.14 & 0.08 \\
\hline 11. & Tuber diameter $(\mathrm{cm})$ & 0.27 & 0.26 & -0.04 & -0.34 & -0.22 & 0.09 & -0.25 \\
\hline 12. & Harvest Index (\%) & 0.16 & 0.31 & -0.27 & -0.32 & 0.02 & -0.17 & 0.12 \\
\hline 13. & Starch content (\%) & 0.17 & -0.33 & -0.03 & -0.25 & -0.21 & -0.28 & 0.55 \\
\hline 14. & HCN content (ppm) & 0.21 & -0.28 & -0.07 & -0.07 & 0.09 & -0.49 & -0.12 \\
\hline 15. & $\begin{array}{l}\text { Postharvest physiological } \\
\text { Deterioration }(\%)\end{array}$ & -0.04 & -0.29 & -0.17 & -0.12 & -0.19 & 0.59 & 0.40 \\
\hline 16. & Tuber yield $\left(\mathrm{t} \mathrm{ha}^{-1}\right)$ & 0.36 & 0.25 & 0.01 & -0.12 & -0.21 & 0.24 & -0.17 \\
\hline
\end{tabular}


Fig.2 Loading of principal component scores (score plot) in cassava genotypes

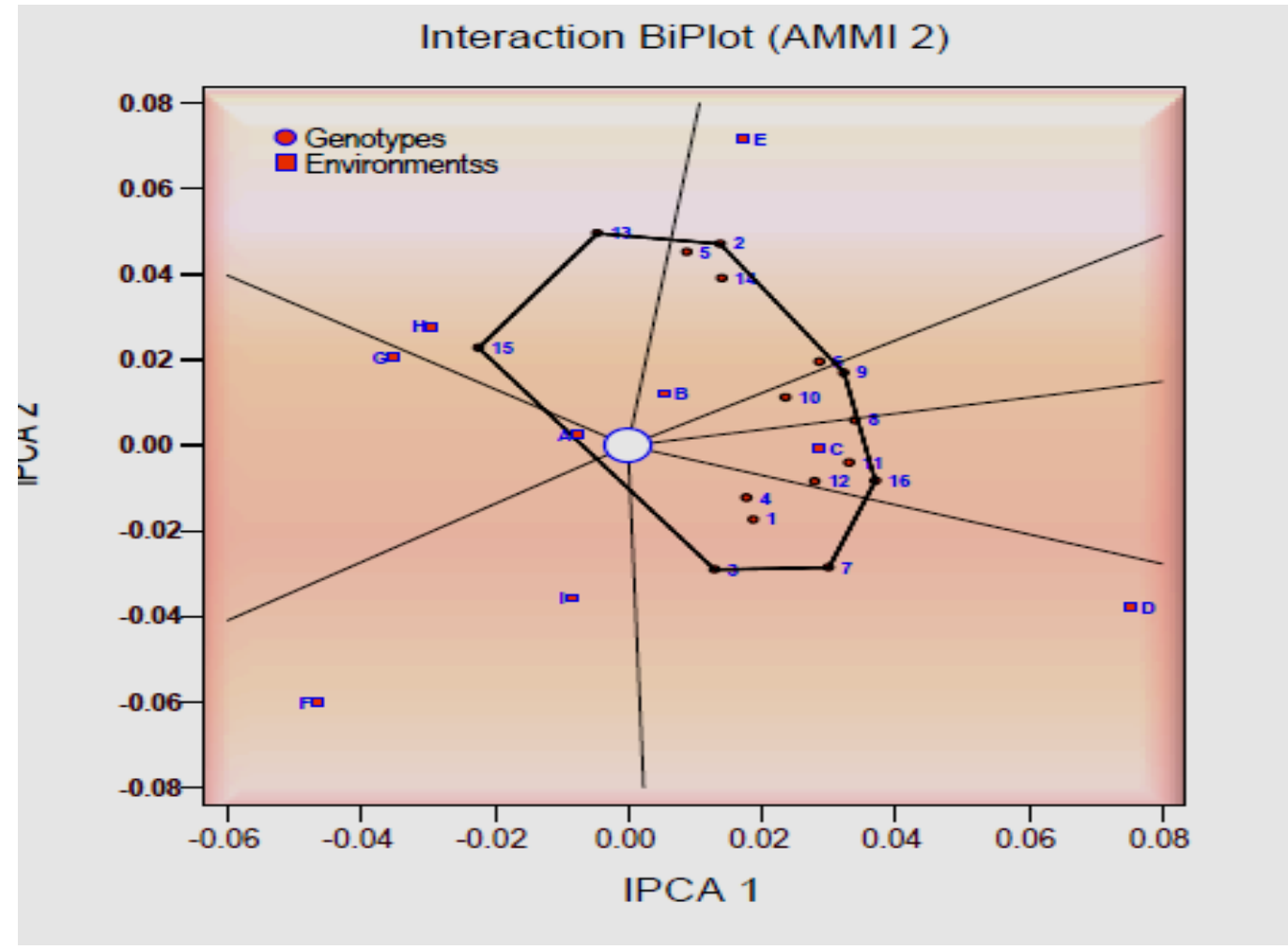

The sixth principal component $\left(\mathrm{PC}_{6}\right)$ contributed 7.17 per cent of total variance and characterized by conspicuously high loadings of post harvest physiological deterioration (0.59), tuber yield (0.24), number of leaves per plant (0.24), HCN content (-0.49), starch content $(-0.28)$ and plant height $(-0.23)$ were noted to explain the variability and it suggest that this component reflects postharvest physiological deterioration, tuber yield per hectare and number of leaves per plant of each genotype. Laila et al., (2015), Babu Rao et al., (2016), Chikoti et al., (2016), Danquah et al., (2016), and Rosliam et al., (2016) were also reported the importance of principal component analysis in genetic divergence studies of cassava.

\section{Acknowledgement}

Utmost gratitude to University Grant Commission for providing financial assistance for the project and All India Coordinated Research Project on Tuber crops, Peddapuram for providing eighty cassava germplasm lines.

\section{References}

Aina, O.O, Dixon, A.G.O. and Akinrinde, E.A. 2007. Genetic variability in cassava as it influences storage root yield in Nigeria. Journal of Biological Science. 7: 765-770.

Alves, A.A.C. 2002. Cassava Botany and Physiology. In: R.J. Hillocks, JM Thresh, A Bellotti, Eds., Cassava: Biology, Production and Utilization: 6790.

Asare, P.A, Galyuon, I.K.A, Sarfo, J.K. and Tetteh, J.P. 2011. Morphological and molecular based diversity studies of some cassava (Manihot esculenta Crantz.) germplasm in Ghana. African 
Journal of Biotechnology. 10(63): 13900-13908.

Babu Rao, B, Ashok, P, Ramanandam, G. and Sasikala, K. 2016. Principal components analysis of agromorphological and yield components among cassava genotypes. Progressive Research- An International Journal. 11(4): 453-56.

Chikoti, P.C, Shanahan, P. and Melis, R. 2016. Evaluation of Cassava Genotypes for Resistance to Cassava Mosaic Disease and Agronomic Traits. American Journal of Plant Sciences. 7: 1122-1128.

Danquah, J.A, Gracen, V.E, Offei, S.K, Asante, I.K. and Aduening, J.M. 2016. Agronomic performance and genotypic diversity for morphological traits among cassava genotypes in the Guinea Savannah Ecology of Ghana. Journal of crop Science and Biotechnology. 19(1): 99-108.

Jackson, J.E. 1991. A user guide to principal components. John Wiley and sons. New York.

Jennings, D.L. and Iglesias, C. 2002. Breeding for crop improvement. In: Hillocks R J, Thresh MJ, Bellotti AC (eds.) Cassava: Biology, production and utilization. CABI International, Oxford: $149-166$.
Laila, F., Zanettaa, C.U., Waluyob, B., Amienc, S. and Karuniawanc, A. 2015. Early Identification of Genetic Diversity and Distance from Indonesia Cassava Potential as Food, Industrial and Biofuel Based on Morphological Characters. Energy Procedia. 65:100 - 106

Meredith, W.R.J, Bridge, R.R. 1984. Genetic conditions to yield changes in upland cotton. In: Fehr WR (ed.) Genetic conditions to yield changes in five major plants CSSA Spec. Publ 7. Madison.WI: 75-87.

Raghu, D, Senthil, N, Saraswathi, T, Raveendran, M, Gnanam, R, Venkatachalam, $\mathrm{R}$, Shanmugasundaram, P. and Mohan, C. 2007. Morphological and Simple sequence repeats (SSR) based finger printings of south Indian cassava germplasm. International journal of Integrative Biology. 1(2): 141- 148.

Rosliam, D.I, Herman, N, Sofyanti, M, Chaniago, Restiani, R. and Novita. L. 2016. Characteristics of 22 Cassava (Manihot esculenta Crantz) Genotypes from riau province, Indonesia. SABRAO Journal of Breeding and Genetics. 48(2): 110-19.

Shore, K. 2002. Decades of cassava research bear fruit. Gene Conserve. 1: 1-4.

\section{How to cite this article:}

Babu Rao, B., D.V. Swami, P. Ashok, B. Kalyana Babu, D. Ramajayam and Sasikala, K. 2018. Genetic Diversity Studies Based on Principal Component Analysis For Yield Attributes in Cassava Genotypes. Int.J.Curr.Microbiol.App.Sci. 7(12): 1424-1430. doi: https://doi.org/10.20546/ijcmas.2018.712.170 